\title{
Progressive Failure Analysis of Glass/Epoxy Composites at Low Temperatures
}

\author{
M. M. Shokrieh, ${ }^{a}$ M. A. Torabizadeh,,${ }^{b, 1}$ and A. Fereidoon ${ }^{b}$ \\ ${ }^{a}$ Iran University of Science and Technology, Tehran, Iran \\ ${ }^{\mathrm{b}}$ University of Semnan, Semnan, Iran \\ 1 Torabizadeh@yahoo.com
}

УдК 539.4

\section{Расчет процесса разрушения стеклоэпоксидных композитов при низких температурах}

\author{
М. М. Шокри ${ }^{\mathrm{a}}$ М. А. Торабизаде ${ }^{\sigma}$, А. Ферейдун ${ }^{\sigma}$ \\ a Иранский университет науки и технологии, Тегеран, Иран \\ ${ }^{\sigma}$ Университет г. Семнана, Иран
}

\begin{abstract}
Применение композитов в космической и криогенной технике обусловливает необходимость определения механических характеристик армированных волокнами стеклоэпоксидных композитов. Однако в настоящее время отсутствуют результаты экспериментальных и расчетных исследований процесса разрушения стеклоэпоксидного ламината (с кониентратором напряжений или без такового) в условиях термомеханического статического нагружения при низких температурах. Предложена модель, позволяющая рассчитать прочесс разрушения в квазиизотропных пластинах композита при низких температурах. Исходное значение предельной нагрузки определяется в упругой постановке. Нагрузка повышается пошагово, для каждого уровня рассчитываются напряжения и оченивается возможное разрушение с помощью соответствующего критеря прочности. Свойства материала в разрушенной части ламината варьируют согласно типу разрушения с использованием ненулевого коэффициента деградачии жесткости. Далее выполняется модифичированная итераџия Ньютона- Рафсона до момента сходимости. Расчет повторяется для каждого прироста нагрузки вплоть до полного разрушения с оченкой предела прочности. Предложенный метод обеспечивает хорошее согласование между расчетными и экпериментальными результатами при комнатной температуре и $-60^{\circ} \mathrm{C}$. Оиенивается влияние низкой температуры на механизм разрушения пластин из композита.
\end{abstract}

Ключевые слова: процесс разрушения, стеклоэпоксидные композиты, низкие температуры.

Introduction. Glass fiber reinforced polymeric (GFRP) composites are promising materials to the cryogenic structures. A reliable and economical design of a composite structure requires a designer to determine the load carrying capacity at low temperature service. Cryogenic performances of GFRP composite are significantly changed in mechanical properties under a cryogenic environment. Several studies have reported on the mechanical properties of composites under cryogenic temperatures. 
Schutz [1] reviewed properties of composite materials for cryogenic applications. He consider several types of matrix and fibers. Baynham et al. [2] investigated transverse mechanical properties of glass reinforced composite materials at $4 \mathrm{~K}$. They demonstrated that the transverse tensile strength of composite is significantly greater than those reported at room temperature. Shindo et al. [3] evaluated the cryogenic compressive properties of G-10CR and SL-ES30 glass-cloth/epoxy laminates. The effects of temperature and specimen geometry on the compressive properties were also examined by compression tests at room temperature, liquid nitrogen temperature and liquid helium temperature. Wang and Zhao [4] presented an analytical approach, which combines the modified shear-lag model and Monte-Carlo simulation technique to simulate numerically the mechanical behaviors including the failure processes, tensile stiffness and strength, etc. for unidirectional composites at room and low temperatures. They found that the tensile moduli and strengths at low temperature are generally larger than those at room temperature. Ip et al. [5] investigated on the influence of low temperature and moisture on the dynamic moduli of thick S2-glass composite beams. They found that both frequencies and moduli of the beam sample were found to exhibit an increasing trend with reducing temperature. Sánchez-Sáez et al. [6] summarized the results of the tests to determine the effect of the low temperature on the mechanical behavior of carbon fiber reinforced epoxy laminates. Tensile and bending static tests were carried out on two laminate lay-ups. Their results showed the changes in the mechanical behavior of this material at different test temperatures. Bechel and Kim [7] identified damage trends in cryogenically cycled carbon/polymer composites. They found several trade-offs affecting damage accumulation from cryogenic cycling, i.e., controlling single ply versus multiple ply damage progression, and processing related property knock-downs versus processing induced residual stresses. Kim and Donaldson [8] described the development of damage in the form of transverse ply microcrack and interlaminar delamination within laminates under combined thermal and mechanical loading. They compared their analytical results with the corresponding results that were experimentally determined and found good agreement. Ifju et al. [9] preformed a study into the development of residual stress as a function of temperature to help provide insight into this situation. They found general agreement between composite laminate theory and the results from the cure referencing method (CRM). Rupnowski et al. [10] predicted mechanical response of a unidirectional composite based on T650-35 graphite fibers embedded in a PMR-15 polyimide resin analytically and numerically as a function of temperature and finally compared the results with available experimental data. Kim et al. [11] studied the tensile properties of a T700/epoxy composite, which had been cycled with thermo-mechanical loads at low temperatures, using an environmental test chamber. Results showed that tensile stiffness significantly increased as temperature decreased, while the thermomechanical cycling had little influence on it. Tensile strength, however, decreased as temperature decreased down to cold temperature (CT), while the decreasing rate of strength was reduced after CT cycling. Takeda et al. [12] examined the thermo-mechanical behavior of cracked G-11 woven glass/epoxy laminates with temperature-dependent material properties under tension at cryogenic temperatures. They found that residual thermal stresses have no significant effect on the Young 
modulus and Poisson's ratio of G-11 woven laminates. In contrast, the effect of residual thermal stresses on the stress distributions near the crack fronts is more pronounced with decreasing of the temperature. Shindo et al. [13] illustrated an experimental and analytical investigation in cryogenic Mode I interlaminar fracture behavior and toughness of SL-E woven glass-epoxy laminates. They performed their tests at room temperature, -196 , and $-269^{\circ} \mathrm{C}$ to evaluate the effect of temperature on the interlaminar fracture toughness. They found that interlaminar fracture toughness increased with temperature decrease to $-196^{\circ} \mathrm{C}$. Melcher and Johnson [14] determined the effect of cryogenic temperature on the adhesive fracture toughness of an adhesively bonded joint with composite adherents. Mode I fracture toughness tests were performed at room temperature and $-196^{\circ} \mathrm{C}$. Experimental results exhibit reduced fracture toughness at the cryogenic temperature.

Shindo et al. [15] described an experimental and analytical study on the cryogenic fatigue behavior of glass fiber reinforced polymer woven laminates under Mode I loading. They found that at low temperature, fatigue loading causes damage to develop in the form of fiber breakage and matrix cracking which lead to material property degradation. Shindo et al. [16] also investigated the cryogenic fatigue delamination behavior of glass fiber reinforced polymer woven laminates under Mode I loading experimentally and numerically. The results showed that fatigue delamination growth rates of the GFRP woven laminates at low temperature were much lower than that at room temperature. Kumagai et al. [17] studied the fatigue damage behavior of GFRP woven laminates in terms of stiffness degradation and residual strength under cyclic loading at low temperature experimentally. Shindo et al. [18] focused on understanding the tension-tension fatigue behavior of woven glass fiber reinforced polymer laminates at cryogenic temperatures. The fatigue tests were performed at room temperature, -196 , and $-269^{\circ} \mathrm{C}$. Failure modes at room temperature featured a macroscopically flat fracture surface. At the cryogenic temperatures, however, delamination appeared.

Lebeas et al. [19] developed a progressive damage model capable of predicting the interaction effect between the post-buckling behavior and various failure modes of composite plates. The analysis was based on comprises stress analysis, failure analysis and material properties degradation modules. Liu and Wang [20], studied the tensile behavior of open-hole composite plates bonded with external composite patches. Zhao et al. [21] investigated numerically and experimentally the progressive failure of tri-axial woven fabric composite panels subjected to uniaxial extension. Tensor polynomial progressive failure procedure was employed with maximum stress criterion, Hoffman criterion and Tsai-Wu criterion. They compared the first and ultimate failure loads, maximum extension displacement, locations and modes of failure with experimental data. Icten and Karakuzu [22] presented an investigation deals with the failure strength and failure mode of a pinned-joint carbon-epoxy composite plate of arbitrary orientations. Takeda et al. [23] illustrated a study on understanding the deformation and progressive failure behavior of glass/epoxy plain weave fabric reinforced laminates subjected to uniaxial tension at cryogenic temperatures. Shindo et al. [24] experimentally and numerically worked on the cryogenic tensile and damage behavior of glass fiber reinforced polymer woven laminates. Akhras and $\mathrm{Li}$ [25] introduced a progressive failure analysis for thick 
composite plates using spline finite strip method. Shokrieh et al. [26] presented a progressive failure analysis for glass/epoxy composite plates at room temperature using classical lamination theory (CLT). They compared the first and ultimate failure loads, and strain to failure with available experimental data.

With respect to literature survey, fewer researches were discussed the progressive damage modeling of a laminated composite with/without stress concentration at low temperature in both experimental and numerical methods. The main objective of present paper is to investigate the tensile failure behavior of glass/epoxy laminated composite with/without stress concentration subjected to thermomechanical loadings at low temperatures experimentally and numerically. A finite element model was developed to perform the progressive failure analysis of quasi isotropic composite plates at low temperatures. The load is increased step by step after detection initial failure load by means of an elastic stress analysis. For each given load, the stresses at each integration point are evaluated and the appropriate failure criterion is applied to inspect for possible failure by using Hashin failure criteria. For the failed elements, material properties are modified according to the failure mode using a non-zero stiffness degradation factor. Then, the modified Newton-Raphson iteration is carried out until convergence is reached. This analysis is repeated for each load increment until the final failure occurs and the ultimate strength is determined. Finally effects of low temperature on the mechanism of failure are determined.

\section{Materials and Specimen Geometry.}

Material Properties. Unidirectional glass fibers, have been used in this investigation as reinforcement material, while epoxy resin has been considered as a matrix material. Hand lay-up method was used to fabricate thin laminates with epoxy resin ML-506 with hardener HA11. Test specimens were cut from laminates according to relevant standard codes. The fiber volume fraction of the composites was $55 \%$.

Specimen Geometry. Quasi-isotropic lay-up $\left([0 / \pm 45 / 90]_{2 s}\right)$ was used in this study for tensile tests at room temperature and $-60^{\circ} \mathrm{C}$. For this reason, thin laminate composed of ten plies of reinforcement with epoxy resin were fabricated with considered configuration, giving a laminate approximately $2 \mathrm{~mm}$ in thickness. For laminate with stress concentration, a central hole was made by a machine. Woven glass/epoxy tabs with tapered ends were locally bonded on each side of the specimens. These tabs allow a smooth load transfer from the grip to the specimen especially for low temperature test. All specimens had a constant cross section with tabs bonded to the ends. The geometry of the specimen with stress concentration for tensile tests is shown in Fig. 1.

\section{Progressive Damage Modeling (PDM).}

Stress Analysis. The first component of the PDM is finite element stress analysis. Consider a composite plate with/without stress concentration (Fig. 1). The plate has width $W=25 \mathrm{~mm}$, length $l=170 \mathrm{~mm}$, thickness $t=2 \mathrm{~mm}$, and central hole $d=6 \mathrm{~mm}$ (if applicable). The plate is a laminated composite with quasiisotropic ply orientation. A two dimensional macro code by APDL of ANSYS [27] is developed to perform finite element analysis. In this paper, the 8-node layered element SHELL 99 is adopted to model the laminates, which allows up to 250 different material layers in the thickness direction in each element without 
significant increase of counting time. Mechanical properties of a unidirectional laminate at room temperature and $-60^{\circ} \mathrm{C}$, which is used as initial values in finite element method and listed in Table 1, were tested by the present authors [28].

$\mathrm{T}$ a b 1 e 1

Mechanical Properties of GFRP at Room and Low Temperatures

\begin{tabular}{||l|c|c||}
\hline \multicolumn{1}{|c|}{ Mechanical properties } & $23^{\circ} \mathrm{C}$ & $-60^{\circ} \mathrm{C}$ \\
\hline Longitudinal elastic modulus $E_{x}(\mathrm{GPa})$ & 19.94 & 28.65 \\
\hline Transverse elastic modulus $E_{y}(\mathrm{GPa})$ & 5.83 & 11.03 \\
\hline Shear elastic modulus $G_{x y}(\mathrm{GPa})$ & 2.11 & 4.21 \\
\hline Longitudinal tensile strength $X_{t}(\mathrm{MPa})$ & 700.11 & 784.98 \\
\hline Longitudinal compression strength $X_{c}(\mathrm{MPa})$ & 570.37 & 731.94 \\
\hline Transverse tensile strength $Y_{t}(\mathrm{MPa})$ & 69.67 & 75.20 \\
\hline Transverse compression strength $Y_{c}(\mathrm{MPa})$ & 122.12 & 186.22 \\
\hline Shear strength $S(\mathrm{MPa})$ & 68.89 & 91.22 \\
\hline \hline
\end{tabular}

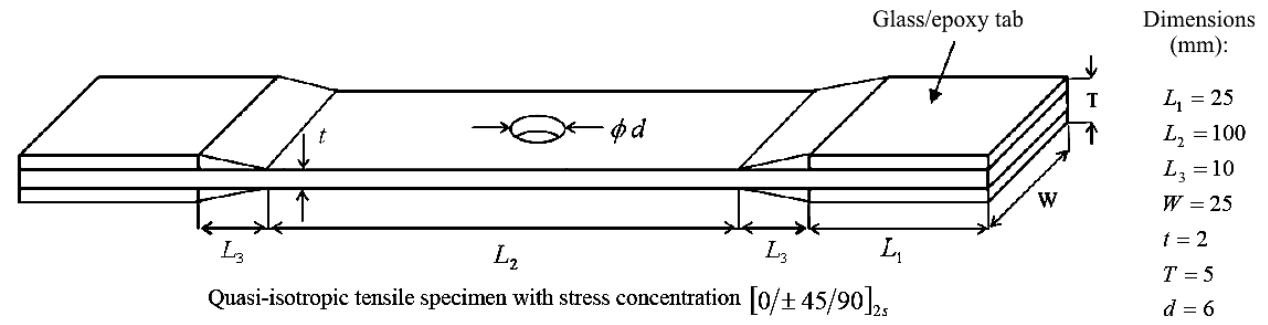

Fig. 1. Geometry of the specimen with stress concentration for tensile test at room temperature and $-60^{\circ} \mathrm{C}$.

In this table, the script $x$ refers to the fiber direction, and $y$ refers to direction perpendicular to the fiber direction. In this study, the stress resultants are defined as follow:

$$
\sigma_{\text {total }}=\sigma_{M}+\sigma_{T}
$$

where $\sigma_{M}$ and $\sigma_{T}$ are the mechanical and thermal stresses, respectively. Thermal stresses are due to decreasing temperature from room temperature to $-60^{\circ} \mathrm{C}$. These stress resultants will be calculated by the following relation:

$$
\sigma_{T}=\left\{\begin{array}{c}
\sigma_{x}^{T} \\
\sigma_{y}^{T} \\
\sigma_{x y}^{T}
\end{array}\right\}=\left[\begin{array}{lll}
\bar{Q}_{11} & \bar{Q}_{12} & \bar{Q}_{16} \\
\bar{Q}_{21} & \bar{Q}_{22} & \bar{Q}_{26} \\
\bar{Q}_{61} & \bar{Q}_{62} & \bar{Q}_{66}
\end{array}\right]\left\{\begin{array}{c}
\varepsilon_{x}^{T} \\
\varepsilon_{y}^{T} \\
\gamma_{x y}^{T}
\end{array}\right\} .
$$

In the above equation, $\left[\bar{Q}_{i j}\right]$ is transformed reduced stiffness matrix for a laminated composite and $\left\{\varepsilon_{i j}^{T}\right\}$ is thermal strain vector which is defined as follow: 


$$
\left\{\begin{array}{c}
\varepsilon_{x}^{T} \\
\varepsilon_{y}^{T} \\
\gamma_{x y}^{T}
\end{array}\right\}=\Delta T\left\{\begin{array}{l}
\alpha_{x} \\
\alpha_{y} \\
\alpha_{x y}
\end{array}\right\},
$$

where $\Delta T$ and $\left\{\alpha_{i j}\right\}$ are temperature difference from room temperature and coefficients of thermal expansion for an angle ply laminate, respectively. Values of $\left\{\alpha_{i j}\right\}$ can be given in terms of the coefficients of thermal expansion for a unidirectional laminate as

$$
\left\{\begin{array}{c}
\alpha_{x} \\
\alpha_{y} \\
\alpha_{x y} / 2
\end{array}\right\}=[T]^{-1}\left\{\begin{array}{c}
\alpha_{1} \\
\alpha_{2} \\
0
\end{array}\right\},
$$

and $[T]$ is a transformation matrix for an angle ply laminate [29].

Failure Criterion. The second part of PDM is failure analysis. By using finite element results, at layer level in each element, stiffness reduction is carried out considering five types of damages: fiber and matrix in tension and compression and fiber-matrix shearing modes. To detect them, a set of two dimensional stress based failure criterion is selected. The following Hashin criteria [30] are used to detect five different failure modes (Table 2). The first two of the failure modes are catastrophic and the others are not.

T a b 1 e 2

\begin{tabular}{|c|c|c|c|}
\hline Condition & Failure criterion & \multicolumn{2}{|c|}{ Failure relation } \\
\hline$\sigma_{x x}>0$ & Fiber tensile failure & $\left(\frac{\sigma_{x x}}{X_{t}}\right)^{2}+\left(\frac{\sigma_{x y}}{S}\right)=e_{F^{+}}^{2}$ & $\begin{cases}e_{F^{+}} \geq 1 & \text { fail } \\
e_{F^{+}}<1 & \text { safe }\end{cases}$ \\
\hline$\sigma_{x x}<0$ & Fiber compressive failure & $\frac{\sigma_{x x}}{X_{c}}=e_{F^{-}} \quad\left\{\begin{array}{l}e_{F} \\
e_{F}\end{array}\right.$ & $\begin{array}{ll}\geq 1 & \text { fail } \\
<1 & \text { safe }\end{array}$ \\
\hline$\sigma_{y y}>0$ & Matrix tensile failure & $\left(\frac{\sigma_{y y}}{Y_{t}}\right)^{2}+\left(\frac{\sigma_{x y}}{S}\right)^{2}=e_{M^{+}}^{2}$ & $\begin{cases}e_{M^{+}} \geq 1 & \text { fail } \\
e_{M^{+}}<1 & \text { safe }\end{cases}$ \\
\hline$\sigma_{y y}<0$ & Matrix compressive failure & $\left(\frac{\sigma_{y y}}{Y_{c}}\right)^{2}+\left(\frac{\sigma_{x y}}{S}\right)^{2}=e_{M^{-}}^{2}$ & $\begin{cases}e_{M^{-}} \geq 1 & \text { fail } \\
e_{M^{-}}<1 & \text { safe }\end{cases}$ \\
\hline$\sigma_{x x}<0$ & Fiber-matrix shearing failure & $\left(\frac{\sigma_{x x}}{X_{c}}\right)^{2}+\left(\frac{\sigma_{x y}}{S}\right)^{2}=e_{F M}^{2}$ & $\begin{cases}e_{F M} \geq 1 & \text { fail } \\
e_{F M}<1 & \text { safe }\end{cases}$ \\
\hline
\end{tabular}

Hashin Failure Criteria

Material Properties Degradation Rules. The last component of PDM is material properties degradation. As failure occurs in a unidirectional ply of a laminate, material properties of that failed ply are changed by a set of sudden material property degradation rules. In the present method, after failure occurrence in a ply of the laminate, instead of inducing real crack, the failed region of the 
unidirectional ply is replaced by an intact ply of lower material properties. A complete set of sudden material property degradation rules for all various failure modes of a unidirectional ply under a uniaxial static stress is explained in the following. The rules must be carefully applied to avoid numerical instabilities during computation by the computer program.

Fiber Tension Failure. Fiber tension failure mode of a ply is a catastrophic mode of failure and when it occurs, the failed material cannot sustain any type or combination of stresses. Thus, all material properties of the failed ply are reduced, as follows:

$$
\begin{gathered}
{\left[E_{x}, E_{y}, G_{x y}, v_{x y}, v_{y x}\right] \rightarrow\left[\lambda_{c d r} E_{x}, \lambda_{c d r} E_{y}, \lambda_{c d r} G_{x y}, \lambda_{c d r} v_{x y}, \lambda_{c d r} v_{y x}\right],} \\
{\left[X_{t}, Y_{t}, X_{c}, Y_{c}, S\right] \rightarrow\left[\lambda_{c d r} X_{t}, \lambda_{c d r} Y_{t}, \lambda_{c d r} X_{c}, \lambda_{c d r} Y_{c}, \lambda_{c d r} S\right]}
\end{gathered}
$$

where $\lambda_{c d r}$ is coefficient of degradation rules. Extensive comparative studies are carried out to study the effect of $\lambda_{c d r}$, which indicates that $\lambda_{c d r}$ would greatly influence the strength prediction and failure mechanism in the progressive damage model. After a careful comparative study, $\lambda_{c d r}=0.001$ is applied in the current model.

Fiber Compression Failure. Fiber compression failure mode of a unidirectional ply is a catastrophic mode of failure and when it occurs, the failed material cannot sustain any type or combination of stresses. Thus, all material properties of the failed ply are reduced. Equations 7 and 8 show this degradation rule

$$
\begin{gathered}
{\left[E_{x}, E_{y}, G_{x y}, v_{x y}, v_{y x}\right] \rightarrow\left[\lambda_{c d r} E_{x}, \lambda_{c d r} E_{y}, \lambda_{c d r} G_{x y}, \lambda_{c d r} v_{x y}, \lambda_{c d r} v_{y x}\right]} \\
{\left[X_{t}, Y_{t}, X_{c}, Y_{c}, S\right] \rightarrow\left[\lambda_{c d r} X_{t}, \lambda_{c d r} Y_{t}, \lambda_{c d r} X_{c}, \lambda_{c d r} Y_{c}, \lambda_{c d r} S\right]}
\end{gathered}
$$

As mentioned, these two modes of failure are catastrophic, therefore if it occurs, the other modes of failure do not need to also be verified.

Matrix Tension Failure. In matrix tension failure mode of a ply, that is not catastrophic failure, only matrix direction affected, therefore other material properties are left unchanged (Eqs. 9 and 10)

$$
\begin{gathered}
{\left[E_{x}, E_{y}, G_{x y}, v_{x y}, v_{y x}\right] \rightarrow\left[E_{x}, \lambda_{c d r} E_{y}, G_{x y}, v_{x y}, \lambda_{c d r} v_{y x}\right],} \\
{\left[X_{t}, Y_{t}, X_{c}, Y_{c}, S\right] \rightarrow\left[X_{t}, \lambda_{c d r} Y_{t}, X_{c}, Y_{c}, S\right] .}
\end{gathered}
$$

Matrix Compression Failure. Matrix compression failure mode results in the same type of damage to the composite ply as the matrix tension failure mode. This mode of failure is not catastrophic; therefore, other material properties are left unchanged:

$$
\begin{gathered}
{\left[E_{x}, E_{y}, G_{x y}, v_{x y}, v_{y x}\right] \rightarrow\left[E_{x}, \lambda_{c d r} E_{y}, G_{x y}, v_{x y}, \lambda_{c d r} v_{y x}\right],} \\
{\left[X_{t}, Y_{t}, X_{c}, Y_{c}, S\right] \rightarrow\left[X_{t}, Y_{t}, X_{c}, \lambda_{c d r} Y_{c}, S\right] .}
\end{gathered}
$$


Fiber-Matrix Shear Failure. In fiber-matrix shearing failure modes of a ply, the material can still carry load in the fiber and matrix directions, but in-plane shear stress can no longer be carried. This is modeled by reducing the in-plane shear material properties of the failed ply, as follows:

$$
\begin{gathered}
{\left[E_{x}, E_{y}, G_{x y}, v_{x y}, v_{y x}\right] \rightarrow\left[E_{x}, E_{y}, \lambda_{c d r} G_{x y}, \lambda_{c d r} v_{x y}, \lambda_{c d r} v_{y x}\right],} \\
{\left[X_{t}, Y_{t}, X_{c}, Y_{c}, S\right] \rightarrow\left[X_{t}, Y_{t}, X_{c}, Y_{c}, \lambda_{c d r} S\right] .}
\end{gathered}
$$

The PDM is an integration of the three important components: stress analysis, failure analysis and material property degradation. The model is capable of simulating the first and final failure load of composite laminates with arbitrary geometry and stacking sequence under tensile static loading at room temperature and $-60^{\circ} \mathrm{C}$.

A computer program, the algorithm of which is shown in Fig. 2, is established to analyze the failure mechanism of composite plates at low temperatures using APDL of ANSYS. All material properties are set to initial values which are experimentally evaluated by present authors [28]. The initial failure load is calculated by means of an elastic stress analysis. The load is increased step by step. For each given load, the stresses at each integration point are evaluated and the appropriate failure criterion is applied to inspect for possible failure. At the point with failure, the material properties are modified according to the failure mode using a non-zero stiffness degradation factor. Then, the modified Newton-Raphson iteration is carried out until convergence is reached. The convergence tolerance is assumed to be 0.001 . This analysis is repeated for each load increment until the final failure occurs and the ultimate strength is determined.

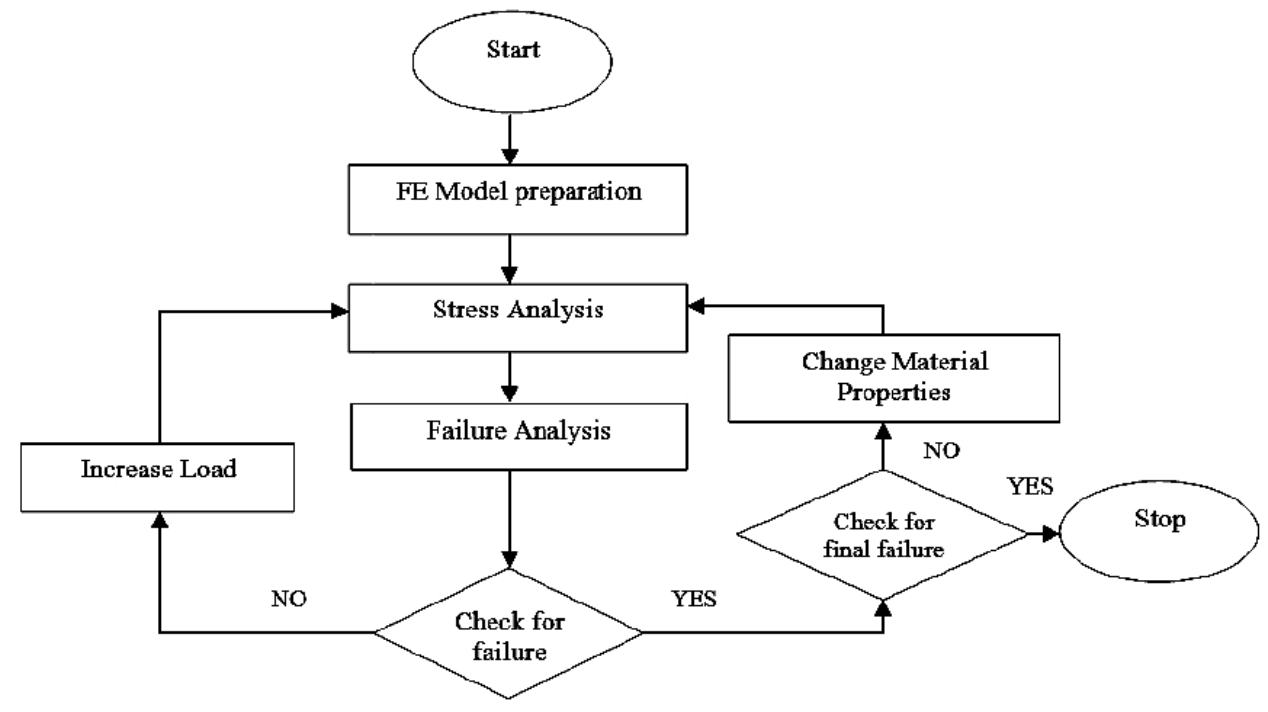

Fig. 2. The algorithm of progressive damage modeling.

Theoretically, the smaller load increment between successive steps, the more accurate analysis result can be achieved. However, a reasonable load increment 
should be prescribed to avoid too much analysis time and to ensure accuracy. After sensitivity analysis on load increment, $1 \mathrm{kN}$ is applied in the current model.

Results and Discussion. The specimens are tested under static tensile loading at room and low temperatures. In each case (with or without stress concentration) at room temperature four specimens and at $-60^{\circ} \mathrm{C}$ five coupons were tested to show statistic scatter of experiments. By statistical evaluation (mean values and standard deviation) reliability of results were appraised. The experimental setup for low temperature tests using an environmental chamber is shown in Fig. 3.

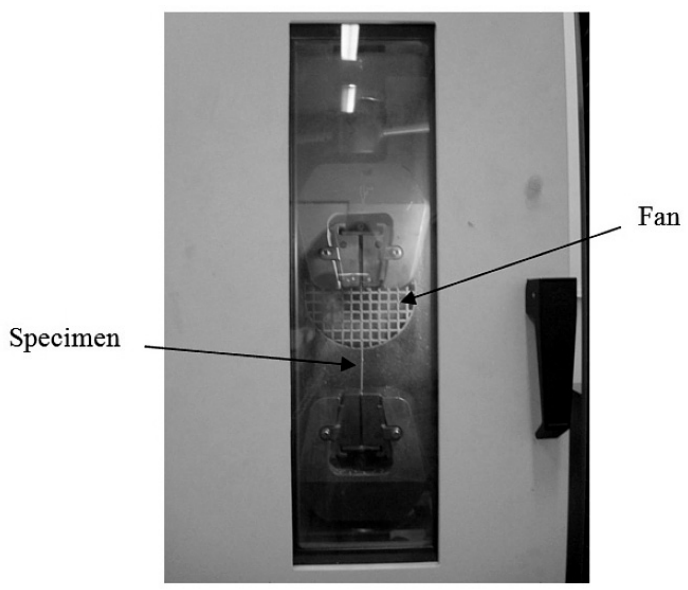

Fig. 3. Environmental chamber for low temperature tests.

The chamber has the ability to cool down its temperature to $-196^{\circ} \mathrm{C}$ by evaporating a liquid cryogenic medium, and liquid nitrogen was used as that medium in the tests. The chamber was equipped with an Instron 5582 as shown in Fig. 4. All experimental tests performed under displacement control with rate of $2 \mathrm{~mm} / \mathrm{min}$. During the tests, a pressurizing device was used to control the cooling time from room temperature to $-60^{\circ} \mathrm{C}$ and maintain an evaporating pressure of $152 \mathrm{kPa}$.

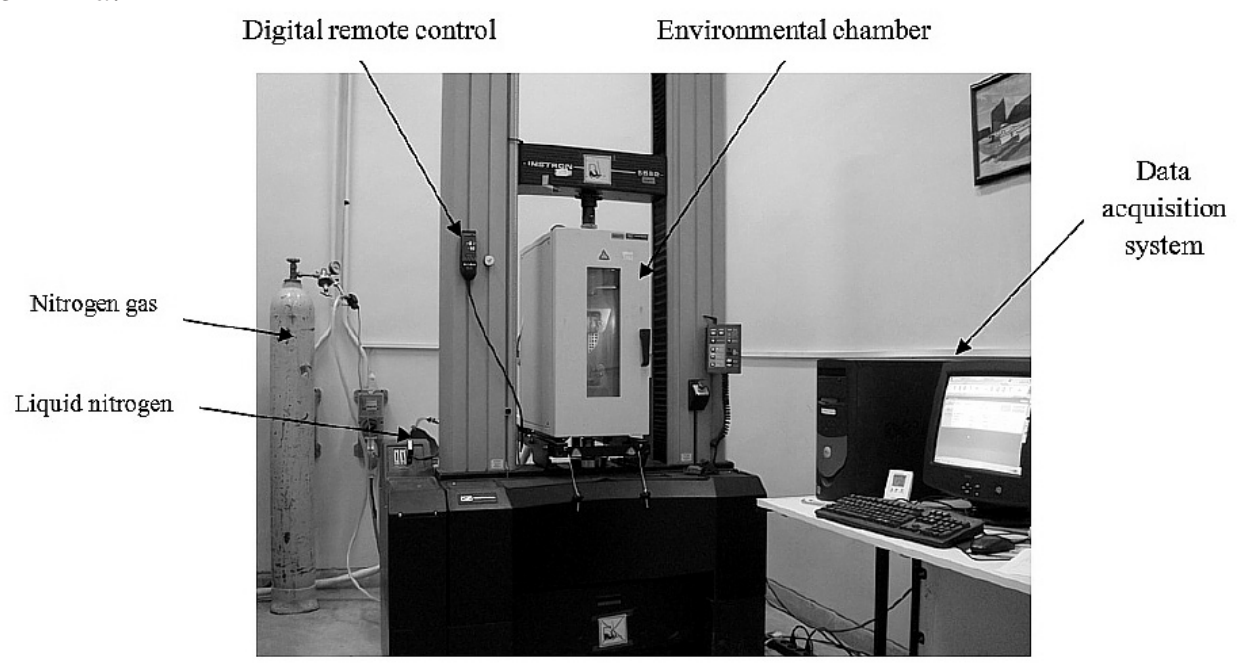

Fig. 4. Experimental set up for mechanical testing at room and low temperatures. 
The average tensile properties such as first ply failure (FPF) load, final failure (FF) load and ultimate strain to failure (USF) for quasi-isotropic laminates with/without stress concentration determined based on results of stress-strain curves from experimental tests and numerical analysis are summarized in Table 3.

$\mathrm{T}$ a b 1 e 3

Average Test Results on Glass/Epoxy Laminated Composite at Room Temperature (RT) and $-60^{\circ} \mathrm{C}$

\begin{tabular}{|c|c|c|c|c|c|c|c|c||}
\hline \multirow{2}{*}{ Characteristic } & \multicolumn{3}{|c|}{ With stress concentration } & \multicolumn{4}{c||}{ Without stress concentration } \\
\cline { 2 - 9 } & \multicolumn{2}{|c|}{ Analytical } & \multicolumn{2}{c|}{ Experimental } & \multicolumn{2}{c|}{ Analytical } & \multicolumn{2}{c|}{ Experimental } \\
\cline { 2 - 9 } & RT & $-60^{\circ} \mathrm{C}$ & RT & $-60^{\circ} \mathrm{C}$ & RT & $-60^{\circ} \mathrm{C}$ & RT & $-60^{\circ} \mathrm{C}$ \\
\hline FPF $(\mathrm{kN})$ & 2.045 & 6.280 & 1.800 & 5.750 & 3.120 & 5.600 & 2.150 & 4.520 \\
\hline FF $(\mathrm{kN})$ & 13.720 & 18.270 & 11.960 & 16.310 & 15.580 & 18.530 & 13.860 & 17.370 \\
\hline USF & 0.041 & 0.036 & 0.040 & 0.037 & 0.056 & 0.058 & 0.055 & 0.057 \\
\hline
\end{tabular}

Figures 5 and 6 show the failure process predicted by the model at room temperature and $-60^{\circ} \mathrm{C}$, respectively. At the FPF load, a mainly obvious damage around the hole of plate is matrix cracking (Figs. 5a and 6a). By increasing the load, other failure modes are also occurred (Figs. 5b and 6b). At the final failure load, the plate breaks along the transverse direction through the central hole edge, the same as noticed in the experimental tests. In this load, the mainly failure mode is fiber breakage (Figs. 5c and 6c). As shown in the following figures, the failure regions of specimens at $-60^{\circ} \mathrm{C}$ at each step is much more than room temperature.
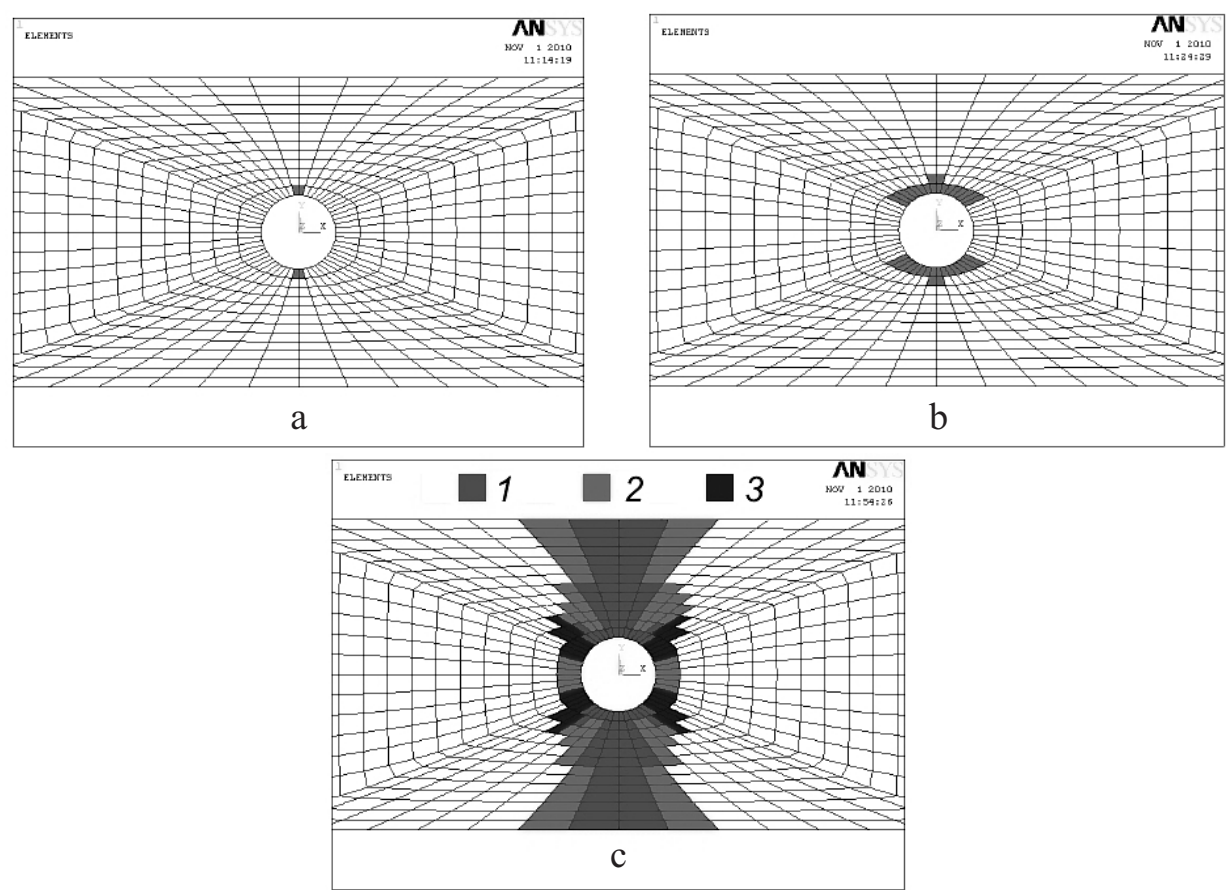

Fig. 5. Failure process of plate with stress concentration at room temperature: (a) $F=2.04 \mathrm{kN}$ (FPF); (b) $F=8 \mathrm{kN}$; (c) $F=13.72 \mathrm{kN}$ (FF). Here and in Fig. 6: (1) fiber breakage, (2) matrix cracking, and (3) fiber-matrix shearing. 
Progressive Failure Analysis of Glass/Epoxy Composites ...
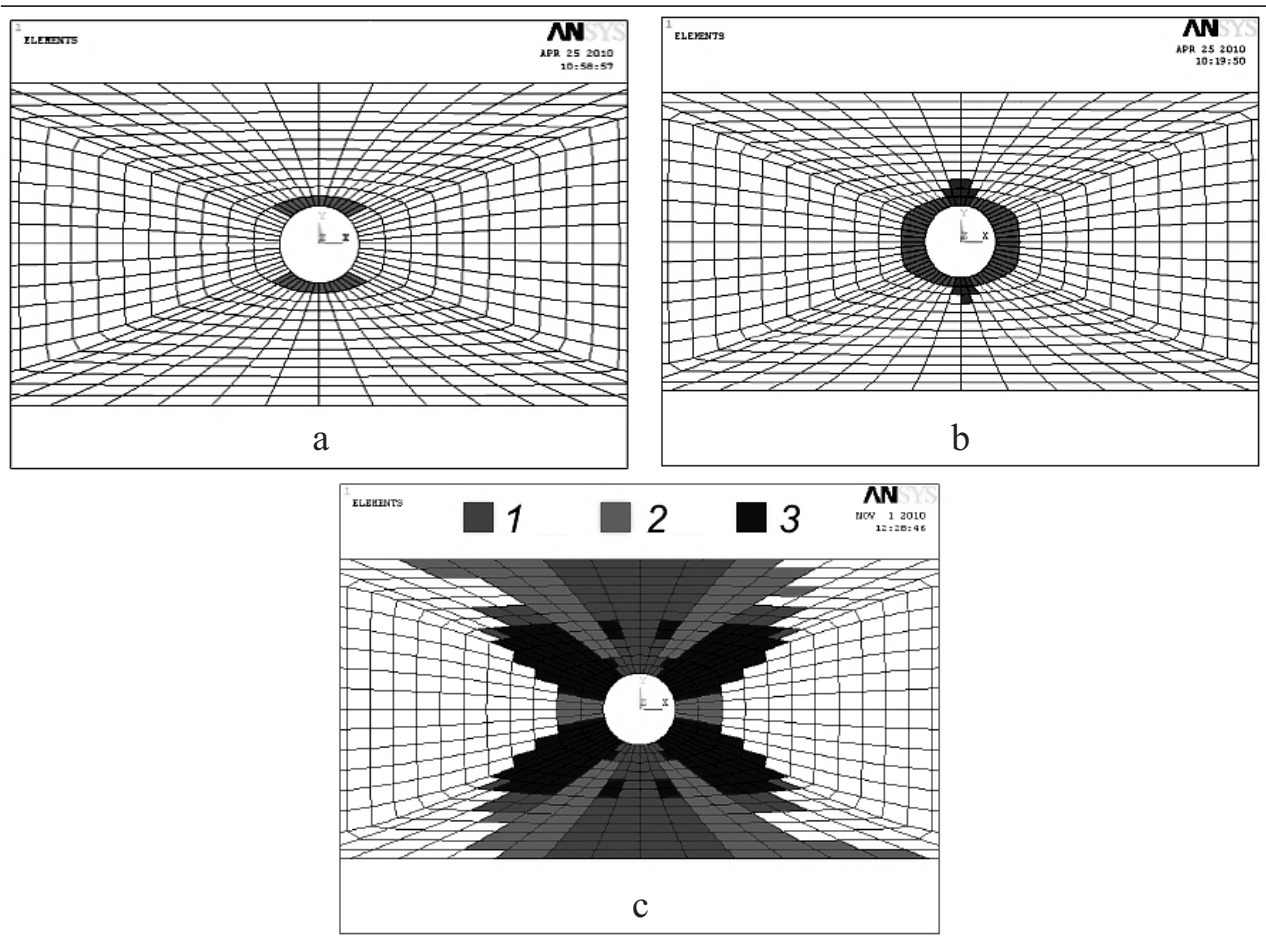

Fig. 6. Failure process of plate with stress concentration at $-60^{\circ} \mathrm{C}$ : (a) $F=6.28 \mathrm{kN}$ (FPF); (b) $F=$ $10 \mathrm{kN}$; (c) $F=18.27 \mathrm{kN}(\mathrm{FF})$.

In all cases, major failure mode was fiber breakage (1), matrix cracking (2), and fiber-matrix shearing (3), respectively, which are shown in the Figs. 5 and 6. Other failure modes are also occurred in the final failure but can not be shown in the figures.

Figure 7 illustrates mean values of tensile strength for quasi-isotropic laminate at room temperature and $-60^{\circ} \mathrm{C}$ with and without stress concentration. This figure also compares experimental results with those obtained from the present finite element model. Results show that strength of laminate increased by decreasing temperature. This is because of change of micromechanical properties of composites at low temperature.

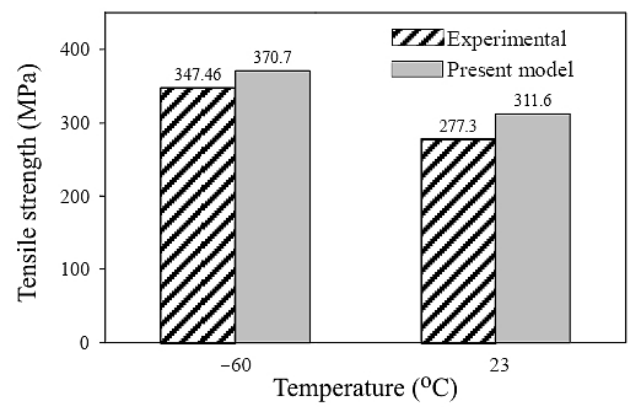

a

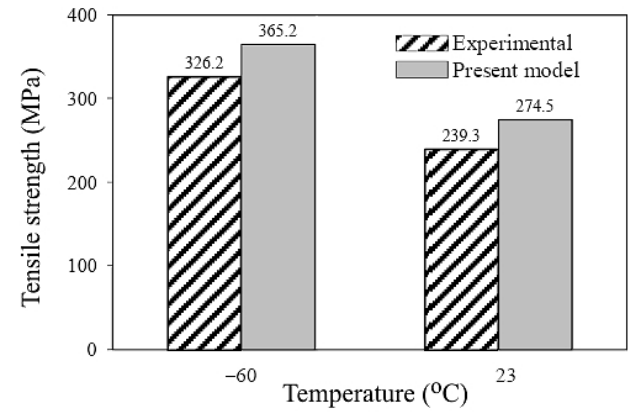

$\mathrm{b}$

Fig. 7. Tensile strength of laminates at different temperatures without (a) and with (b) stress concentration. 


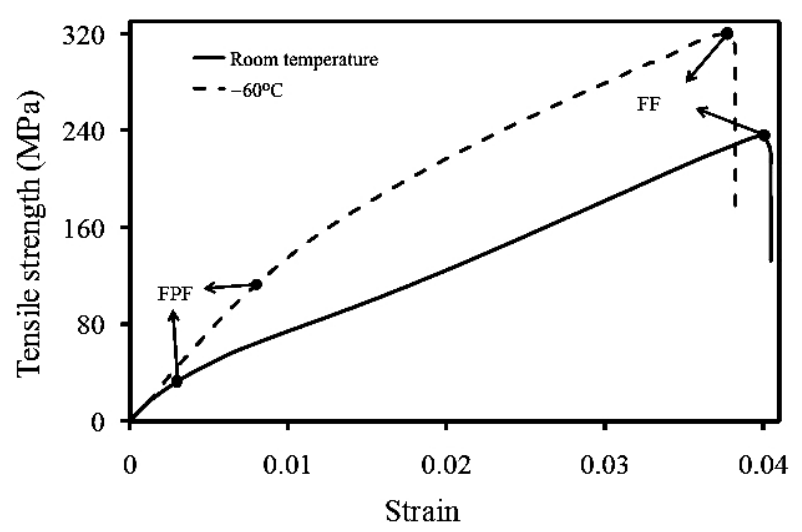

Fig. 8. Typical stress-strain curve for quasi-isotropic laminate with central hole at room temperature and $-60^{\circ} \mathrm{C}$.

Figure 8 shows typical stress-strain curve for the laminate with stress concentration based on experimental results at room temperature and $-60^{\circ} \mathrm{C}$.

Failure mechanism of tested specimens with central hole at room temperature and $-60^{\circ} \mathrm{C}$ are different. Figure 9 shows failed specimens at two different temperatures. From a visual inspection, there is a small amount of tab debonding near the gage area for both two cases with more fiber pull-out for low temperature specimen. At low temperature, because of the interface between fiber and matrix are much weaker and the fiber debond from the matrix, synchronous with fiber breakage, matrix cracking and a few fiber-matrix shearing were occurred. However, the mainly failure mode for all cases is fiber breakage and matrix cracking.

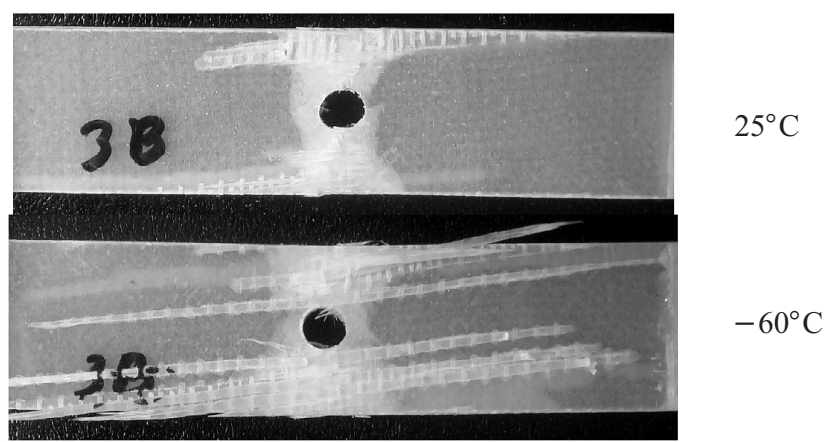

Fig. 9. Failure regions of glass-fiber reinforced epoxy composites at room temperature and $-60^{\circ} \mathrm{C}$.

Conclusions. Tensile failure behavior of glass/epoxy laminated composite subjected to thermo-mechanical loadings at low temperatures with/without stress concentration was investigated experimentally and numerically. A finite element code was utilized to model the progressive failure analysis of quasi-isotropic composite plates at low temperatures under static loading. For each given load step, the stresses at each integration point are evaluated and the appropriate failure criterion is applied to inspect for possible failure by using Hashin failure criteria. At the point with failure, the material properties are modified according to the failure mode using a non-zero stiffness degradation factor. In case of failure detection, because of nonlinear behavior, the modified Newton-Raphson method 
was carried out until convergence is reached. This analysis is repeated for each load increment until the final failure occurs and the ultimate strength is determined. Based on the results of the present study, the following conclusions can be drawn:

1. The stress-strain behavior of laminate under tensile loads was linear elastic until first ply failure (FPF). After this, the behavior of laminate was nonlinear until final failure occurred. This trend was observed for laminated composite with/ without stress concentration at both temperatures.

2. The slope of the stress-strain curve and the strength of laminate increased as the temperature decreased to $-60^{\circ} \mathrm{C}$. On the other hand, by decreasing temperature, strain to failure decreased slightly. Thus, in spite of improvement in strength and stiffness of composites under static loading at low temperatures in comparison with room temperature, their strain to failure under these environmental conditions becomes weaker.

3. The failure mode of laminated composite at low temperature changes from matrix cracking at FPF to mixed mode failure (fiber breakage, fiber matrix shearing and matrix cracking) at final failure load.

4. Failure type of laminates under various loadings was affected by low temperature. It was found that, by decreasing temperature a small amount of tab debonding occurred near the gage area with more fiber pull-out. Also, due to weakness of the interface between fiber and matrix at low temperature, fiber debonds the matrix. Therefore, it may be concluded that the lower temperature affects the micro mechanisms of damage.

5. Good agreement was achieved between results from experimental and analytical calculation at room temperature and $-60^{\circ} \mathrm{C}$. This agreement also showed the validity of model.

\section{Резиме}

Використання композитів у космічній і криогенній техніці зумовлює необхідність визначення механічних характеристик армованих волокнами склоепоксидних композитів. Однак до сьогодні відсутні дані експериментальних і розрахункових досліджень процесу руйнування склоепоксидного ломіната (iз концентратором напружень або без) в умовах статичного навантаження за низьких температур. Запропоновано модель, що дозволяє розрахувати процес руйнування в квазіізотропних пластинах за низьких температур. Початкова величина граничного навантаження визначається у пружній постановці. Навантаження збільшується ступенево, для кожного рівня розраховуються напруження й оцінюється можливе руйнування за допомогою критерію міцності. Властивості матеріалу в частині ламіната, де мало місце руйнування, варіюють згідно 3 типом руйнування 3 використанням ненульового коєфіцієнта деградації жорсткості. Далі виконується модифікована ітерація Ньютона-Рафсона до моменту збіжності. Розрахунок повторюється для кожного приросту навантаження аж до повного руйнування 3 оцінкою границі міцності. Запропонований метод забезпечує хорошу відповідність між розрахунковими й експериментальними результатами за температури $-60^{\circ} \mathrm{C}$ та кімнатної. Оцінюється вплив низької температури на механізм руйнування пластин із композита. 
1. J. S. Schutz, "Properties of composite materials for cryogenic applications," Cryogenics, 38, Issue 1, 3-12 (1998).

2. D. E. Baynham, D. Evans, S. J. Gamage, et al., "Transverse mechanical properties of glass reinforced composite materials at $4 \mathrm{~K}$," Cryogenics, 38, Issue 1, 61-67 (1998).

3. Y. Shindo, H. Tokairin, K. Sanada, et al., "Compression behavior of glasscloth/epoxy laminates at cryogenic temperature," Cryogenics, 39, Issue 10, 821-827 (1999).

4. X. F. Wang and J. H. Zhao, "Monte-Carlo simulation to the tensile mechanical behaviors of unidirectional composites at low temperatures," Cryogenics, $\mathbf{4 1}$, Issue 9, 683-691 (2001).

5. K. H. Ip, P. K. Dutta, and D. Hui, "Effects of low temperature on the dynamic moduli of thick composite beams with absorbed moisture," Composites Part B: Engineering, 32, Issue 7, 599-607 (2001).

6. S. Sánchez-Sáez, T. Gómez-del Rio, E. Barbero, et al., "Static behavior of CFRPs at low temperatures," Composite Part B: Engineering, 33, Issue 5, 383-390 (2002).

7. V. T. Bechel and R. Y. Kim, "Damage trends in cryogenically cycled carbon/ polymer composites," Compos. Sci. Technol., 64, Issue 12,1773-1784 (2004).

8. R. Y. Kim and S. L. Donaldson, "Experimental and analytical studies on the damage initiation in composite laminates at cryogenic temperature," Compos. Struct., 76, 62-66 (2006).

9. P. Ifju, D. Myers, and W. Schultz, "Residual stress and thermal expansion of graphite epoxy laminates subjected to cryogenic temperatures," Compos. Sci. Technol., 66, 2449-2455 (2006).

10. P. Rupnowski, M. Gentz, and M. Kumosa, "Mechanical response of a unidirectional graphite fiber/polyimide composite as a function of temperature," Compos. Sci. Technol., 66, 1045-1055 (2006).

11. M. G. Kim, S. G. Kang, C. G. Kim, and C. W. Kong, "Tensile response of graphite/epoxy composite at low temperatures," Compos. Struct., 79, No. 1, 84-89 (2007).

12. T. Takeda, Y. Shindo, and F. Narita, "Three-dimensional thermoelastic analysis of cracked plain weave glass/epoxy composites at cryogenic temperatures," Compos. Sci. Technol., 64, 2353-2362 (2004).

13. Y. Shindo, K. Horiguchi, R. Wang, and H. Kudo, "Double cantilever beam measurement and finite element analysis of cryogenic Mode I interlaminar fracture toughness of glass-cloth/epoxy laminates," J. Eng. Mater. Technol., 123, 191-197 (2001).

14. R. J. Melcher and W. S. Johnson, "Mode I fracture toughness of an adhesively bonded composite-composite joint in a cryogenic environment," Compos. Sci. Technol., 67, Issue 3-4, 501-506 (2007).

15. Y. Shindo, A. Inamoto, and F. Narita, "Characterization of Mode I fatigue crack growth in GFRP woven laminates at low temperatures," Acta Mater., 53, 1389-1396 (2005). 
16. Y. Shindo, A. Inamoto, F. Narita, and K. Horiguchi, "Mode I fatigue delamination growth in CFRP woven laminates at low temperatures," Eng. Fract. Mech., 73, 2080-2090 (2006).

17. S. Kumagai, Y. Shindo, and A. Inamoto, "Tension-tension fatigue behavior of GFRP woven laminates at low temperatures," Cryogenics, 45, Issue 2, $123-$ 128 (2005).

18. Y. Shindo, S. Takano, K. Horiguchi, and T. Sato, "Cryogenic fatigue behavior of plain weave glass/epoxy composite laminates under tension-tension cycling," Cryogenics, 46, Issue 11, 794-798 (2006).

19. G. Labeas, S. Belesis, and D. Stamatelos, "Interaction of damage failure and post-buckling behavior of composite plates with cut-outs by progressive damage modeling," Composites Part B: Engineering, 39, Issue 2, 304-315 (2008).

20. X. Liu and G. Wang, "Progressive failure analysis of bonded composite repairs," Compos. Struct., 81, 331-340 (2007).

21. Q. Zhao, S. V. Hoa, and S. V. Ouellette, "Progressive failure of triaxial woven fabric (TWF) composites with open holes," Compos. Struct., 65, 419-431 (2004).

22. B. M. Icten and R. Karakuzu, "Progressive failure analysis of pin-loaded carbon-epoxy woven composite plates," Compos. Sci. Technol., 62, 12591271 (2002).

23. T. Takeda, S. Takano, Y. Shindo, and F. Nurita, "Deformation and progressive failure behavior of woven-fabric-reinforced glass/epoxy composite laminates under tensile loading at cryogenic temperatures," Compos. Sci. Technol., 65, 1691-1702 (2005).

24. Y. Shindo, S. Takano, F. Narita, and K. Horiguchi, "Tensile and damage behavior of plain weave glass/epoxy composites at cryogenic temperatures," Fusion Eng. Design, 81, Issue 20-22, 2479-2483 (2006).

25. G. Akhras and W. C. Li, "Progressive failure analysis of thick composite plates using spline finite strip method," Compos. Struct., 79, 34-43 (2007).

26. M. M. Shokrieh, M. A. Torabizadeh, and A. Fereidoon, "Progressive failure analysis of composite plates," in: Proc. of 8th Iranian Aerospace Society Conference (Oct. 25-26, 2009, Esfahan).

27. ANSYS, Ver. 10, ANSYS Inc., Canonsburg, PA (2005).

28. M. M. Shokrieh, M. A. Torabizadeh, and A. Fereidoon, "An investigation on damage of quasi-isotropic laminated composite," in: Proc. of 18th Annual International Conference on Mechanical Engineering, Tehran (2010).

29. A. K. Kaw, Mechanics of Composite Materials, Taylor and Francis Group, LLC (2006).

30. M. M. Shokrieh, Progressive Fatigue Damage Modeling of Composite Materials, Ph.D. Thesis, McGill University (1996). 